\title{
Slippery Talk of Parliament's Architecture: Canadian, Canadian British, or Anglo-American?
}

\section{Christopher A. Thomas}

Volume 29, numéro 1-2, 2004

URI : https://id.erudit.org/iderudit/1069675ar

DOI : https://doi.org/10.7202/1069675ar

\section{Aller au sommaire du numéro}

\section{Éditeur(s)}

UAAC-AAUC (University Art Association of Canada | Association d'art des universités du Canada)

\section{ISSN}

0315-9906 (imprimé)

1918-4778 (numérique)

\section{Découvrir la revue}

\section{Citer cet article}

Thomas, C. A. (2004). Slippery Talk of Parliament's Architecture: Canadian, Canadian British, or Anglo-American? RACAR : Revue d'art canadienne / Canadian Art Review, 29(1-2), 14-27. https://doi.org/10.7202/1069675ar

\section{Résumé de l'article}

L'historiographie classique de l'architecture canadienne - formulée en termes patriotiques comme dans bien des pays - a pris le parti de traiter les styles néo-médiévaux, y compris le gothique victorien et le « style château », comme particulièrement canadiens. Comme cette approche, que l'on retrouve dans les textes de R.H. Hubbard et de Alan Gowans, devint partie intégrante du nationalisme canadien d'après-guerre et coïncida plus ou moins avec la célébration du centenaire de la Confédération en 1967, elle s'inscrivit dans le processus identifié par le critique littéraire Northrop Frye comme un essai de définition du " génie canadien ». Cet article trace l'histoire de ce trope, de cette convention de l'histoire de l'architecture en s'appuyant sur l'exemple des comptes-rendus (y compris le mien) de la construction du Parlement à Ottawa (1859-76). Ainsi encapsulée, l'histoire du projet peut être confrontée à l'historiographie classique en soulevant des questions au sujet de sa genèse et de son style mises en évidence par une réexamination des faits historiques. On mettra l'accent sur la prise de conscience de la Province du Canada dans les années 1850, soulignée par le nom de Nova Britannia proposé par Alexander Morris. On explorera la signification de l'emploi du style néo-gothique « High Victorian » du Parlement par l'architecte Thomas Fuller (1823-98), en tenant compte du fait qu'il connaissait le projet contemporain de constuction des «Public Offices » à Londres; et le Parlement d'Ottawa est comparé au nouveau palais de Westminster et au capitole des Étas-Unis à Washington (considérablement agrandi à cette époque). Après cette étude détaillée, on est amené à se demander si le style du Parlement doit être - ainsi que le suggère le titre de cet article - qualifié de « canadien, canadien-britanique ou anglo-américain » et, implicitement, quel regard poser sur la Province du Canada durant cette période.
Tous droits réservés (C) UAAC-AAUC (University Art Association of Canada | Association d'art des universités du Canada), 2005
Ce document est protégé par la loi sur le droit d'auteur. L’utilisation des services d'Érudit (y compris la reproduction) est assujettie à sa politique d'utilisation que vous pouvez consulter en ligne.

https://apropos.erudit.org/fr/usagers/politique-dutilisation/ 


\title{
Slippery Talk of Parliament's Architecture: Canadian, Canadian British, or Anglo-American?
}

\author{
ChrISTOPHER A. THOMAS, UNIVERSITY OF VICTORIA
}

To the memory of Alan Gowans (1923-2001)

\section{Résumé}

L'historiographie classique de l'architecture canadienne - formulée en termes patriotiques comme dans bien des pays - a pris le parti de traiter les styles néo-médiévaux, y compris le gothique victorien et le "style château," comme particulièrement canadiens. Comme cette approche, que l'on retrouve dans les textes de R.H. Hubbard et de Alan Gowans, devint partie intégrante du nationalisme canadien d'après-guerre et coïncida plus ou moins avec la célébration du centenaire de la Confédération en 1967, elle s'inscrivit dans le processus identifié par le critique littéraire Northrop Frye comme un essai de définition du "génie canadien." Cet article trace l'histoire de ce trope, de cette convention de l'histoire de l'architecture en s'appuyant sur l'exemple des comptes-rendus (y compris le mien) de la construction du Parlement à Ottawa (1859-76). Ainsi encapsulée, l'histoire du projet peut être confrontée à l'historiographie classique en soulevant des questions au sujet de sa genèse et de son style mises en évidence par une réexamination des faits historiques. On mettra l'accent sur la prise de conscience de la Province du Canada dans les années 1850, soulignée par le nom de Nova Britannia proposé par Alexander Morris. On explorera la signification de l'emploi du style néo-gothique "High Victorian" du Parlement par l'architecte Thomas Fuller (1823-98), en tenant compte du fait qu'il connaissait le projet contemporain de constuction des "Public Offices" à Londres; et le Parlement d'Ottawa est comparé au nouveau palais de Westminster et au capitole des Étas-Unis à Washington (considérablement agrandi à cette époque). Après cette étude détaillée, on est amené à se demander si le style du Parlement doit être - ainsi que le suggère le titre de cet article - qualifié de "canadien, canadienbritanique ou anglo-américain," et, implicitement, quel regard poser sur la Province du Canada durant cette période.
I n 1968, architectural historian Alan Gowans argued that the High Victorian eclectic, neo-medieval architecture of University College, Toronto (1856-1859), and the federal Parliament Buildings at Ottawa, begun in 1859 (fig. 1), established for Canada a national style in architecture. "These buildings and their counterparts and descendants all over the country for the next thirty years," he wrote, "form a body of architecture which ... is perhaps the greatest single witness to the character of the new nation created in 1867." "To Gowans, the picturesqueness of High Victorianism and the range of sources on which it drew embodied all the gangly hopefulness of Canada at Confederation, the centennial of which had fallen the year before his essay appeared. Questionable and contradictory in some respects though it was, Gowans's argument was full of the outspoken verve for which he was known and had a certain indisputable validity, for the federal union of Canada was a product of the High Victorian age - roughly the 1850 s to the 1880 s - and these decades did indeed see vast amounts of building, especially public building.

In documenting and celebrating a "National Style," Gowans was echoing a position mooted after World War II by R.H. Hubbard, curator of Canadian art at the National Gallery of Canada. Hubbard's claim, in turn, was rooted in the contemporary reevaluation of the Picturesque and of Victoriana in Britain. In a pioneering article on Canadian architecture that appeared in 1954, Hubbard had called Gothic Revival "the country's first national expression in architecture."2 But Gowans advanced his argument more forcefully than Hubbard, in con- sideration of social and aesthetic changes that had occurred in the decade between their proclamations. During that time Victorian design had gained in popularity in Britain and America, inviting Canadians, too, to take a second look; and the celebration of the centennial of Canada's federal government in 1967 had thrust Confederation into the spotlight as the defining moment in the emergence of an independent northern nationality. ${ }^{3}$

Gowans's declaration that nineteenth-century Canadian architects had practised in germ form a national style, of which the "first" Parliament Buildings were exemplary, ${ }^{4}$ manifested both an art historian's preoccupation with style and the cresting of postwar Canadian nationalism in the run-up to the centennial. Articulated at a critical moment, that argument has remained an idée fixe of Canadian architectural historiography to this day, repeated endlessly. ${ }^{5}$ The claim glosses over a number of awkward historical realities, however, among them differences between the rhetorical construction of Parliament at the time of its building and critical interpretation today. Needed, ultimately, is a history of the criticism of Parliament's architecture; this article aims to make a start by asking what the choice of neoGothic architecture meant in the cultural and political circumstances of its time. This may begin to unsettle the effortless naturalness, the transparent "objectivity," of the nationalist historiography of Canadian architecture by demonstrating that portraying the federal Parliament as an architectural symbol of the modern, independent Canada is historically misleading: it folds other and earlier versions of Canada under those of the recent past, with the effect of concealing them. 
Figure I. Fuller \& Jones, architects. Canadian Parliament Building, Ottawa, 1859-66 (with some elements later). Main front, April 1915. A.W. Campbell, photographer. (Photo: National Archives of Canada, PA 130626).

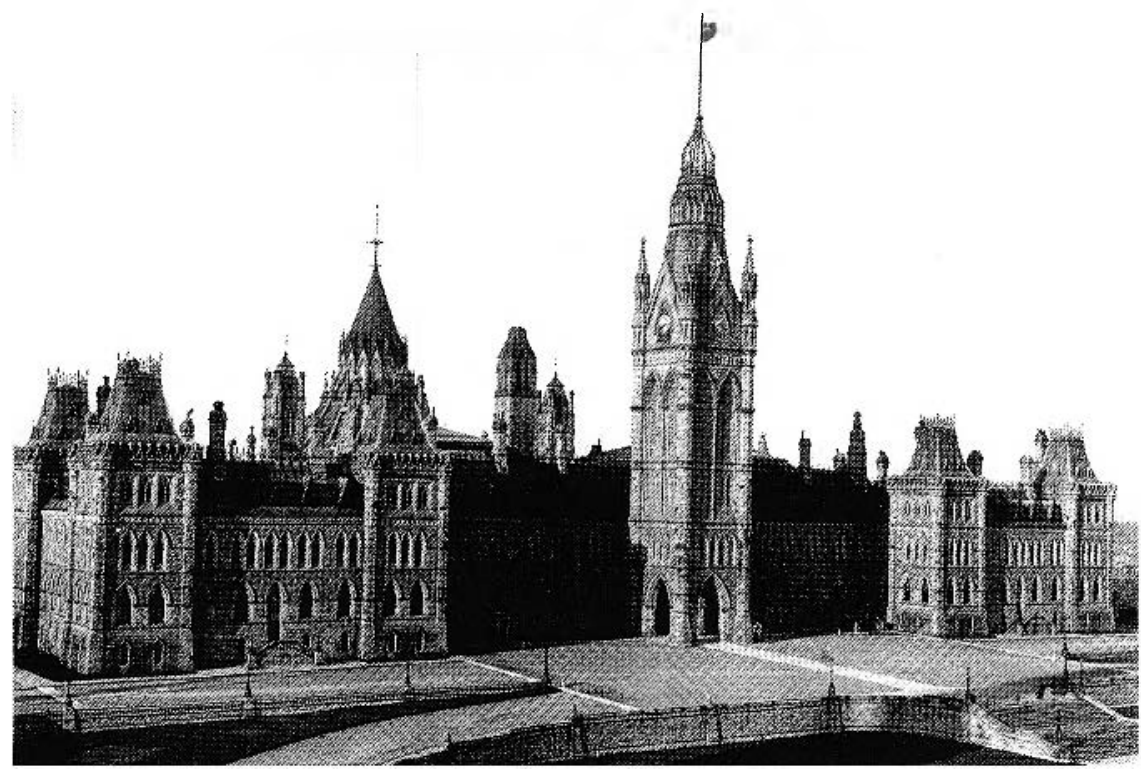

The interpretation of nineteenth-century architecture in Canada practised by Hubbard, Gowans, and other postwar writers gave that architecture a history to correspond to a nationalist political epic or chronology privileging Confederation and implying that constitutional developments determined the course of aesthetic practice. Although I have singled out two writers because I think they made the argument that concerns me in the highest key, they were not alone. In 1959, John Bland of McGill University wrote: "When one sees pictures of the vast parliamentary buildings rising in a pioneer town, one senses the grandeur of the idea of a united self-governing country which is now taken for granted. At the time of their construction, the Parliament Buildings in Ottawa were intended to be symbols of the immense achievement of political union." 6 I will return to Bland's attribution of intention later; for now, it is enough to note how neatly it dovetails with other statements I have quoted. The retrospective nationalizing of the building of Parliament can be read against a longstanding tradition in Canadian architectural discourse, probably originating in the late nineteenth century, that emphasized national identity as a - even the determiner in architectural design and criticism. ${ }^{7}$ What was new in the 1950s and especially the 1960s was a marked increase in writing about Canadian historical architecture, particularly from within art history, a discipline that ballooned in Canadian universities in the period. ${ }^{8}$ Art historians of that period tended to frame architectural history in the same stylehistorical terms as the other arts, relying especially on comparative methods demonstrated in Heinrich Wölfflin's Principles of Art History (English edition, 1932). Often, surveys of architectural history such as those I have referred to were internally structured to present historical architecture as a "usable past" for contemporary Canadian architecture, which was starting to attract international attention, practically for the first time. ${ }^{?}$

Patriotic historiography cut across cultural disciplines, and the academic quest for the "really, really Canadian" in art and architecture was part of a larger nationalist discourse, which, though easiest to see operating in literary studies, drew considerable inspiration from evidence in painting, especially of the Group of Seven. ${ }^{10}$ As early as 1943, Northrop Frye of Toronto's Victoria College - an institution not given to doubting its centrality in national life - had argued, with poetry as evidence, "the existence of a definable Canadian genius ... which is neither British nor American but, for all its echoes and imitations and second-hand ideas, peculiarly our own." "So, Gowans's and Hubbard's retrospective assertions of a national style in architecture were not sui generis, but one front in a more or less conscious campaign of cultural nation-building already in progress for several decades, which enjoyed the support of Canadian cultural institutions and a succession of federal governments in the postwar period. ${ }^{12}$ Emphasizing styles, architectural history constructed a canon of (somewhat) great buildings, for the most part in the Maritime provinces and "older" central Canada, belonging to one or other "national tradition" and individualistically attributed, nearly always, to white male architectural pioneers. ${ }^{13}$ In this way a small, classic discipline of Canadian architectural history was built, embodying Canadians' generally Anglo-Saxon sense of collective selfhood - the unspecified "we" interrogated by James Viloria in an important recent article. ${ }^{34}$

My own master's thesis in fine arts, presented to the University of 'Toronto in 1978 and titled "Dominion Architecture: Fuller's Canadian Post Offices, 1881-1896," was a particularly direct example of such writing-as-nationalism. From it Thomas Fuller (1823-1898), Chief Architect of the federal Department of Public Works (long after he had designed Parliament), emerged, largely independent of his various partners, collaborators, and subordinates, as the arbiter of federal architectural taste and main instigator of a "Dominion image." This portrait of Fuller, which - I hasten to add - is not without historical foundation, made of Fuller a Canadian cultural nationalist and aesthetic analogue to Sir John A. Macdonald, whose governments he served, despite the inconveniences that he was reared and trained in the west of England, worked in the West Indies, and was involved, for a substantial period after the Parliament 
Buildings in Ottawa were complete, in two large public-building projects in the United States that can be read in relation to what is for Canadians the ultimate embarrassment and stumbling-block: post-Civil-War American nationalism. ${ }^{15}$ However, I ignored these awkward facts, which might have suggested viewing Fuller as an Anglo-American architect, to concentrate on the way he set Canadian federal design on what appeared its organic neo-medieval path for the next two generations. Today, with the amplification contemporary critical discourse offers, one tends to ask different questions of Fuller's career, such as: What did Canadianness signify in his time? How much was he responsible for establishing the representational conventions that embodied Canadianness? What roles did his collaborators play, especially while he was a bureaucratic architect in the 1880 s and 1890s? And, given the shameless deployment of federal political patronage by Macdonald and his Québec lieutenant and longtime Minister of Public Works, Hector Langevin, should Fuller be viewed as a national or a partisan architect? (After all, he resigned when the Conservatives lost power in 1896.) Here I tackle only the first of these questions: What did it mean in 1859 to be or to appear "Canadian," vis à vis what it meant a century later?

Representing the Parliament built just before Confederation as the arch-symbol of the idea of Canada was an understandable rhetorical strategy for nationalist critics and historians in the mid-twentieth century. ${ }^{16}$ After all, the complex on what is now called Parliament Hill houses the federal legislature and, originally, the executive officer representing the monarch. (Early governors general had their state office in the East Block.) National capitols are gilt-edged rhetorical symbols, more apt than almost any other building type to have their design-flaws and limitations overlooked and to be seen as mirrors of the State and the values said to undergird it. ${ }^{17}$ Of the rather ungainly U.S. Capitol, Dell Upton observes, "[I]ts builders have been more interested in building a mythology, the central task of an architecture of citizenship, than a coherent formal composition." 18 Thick on the ground though patriotic interpretations of Canada's Parliament lay a quarter-century ago, we should not suppose ourselves beyond roseate characterizations, either: a book published in 1996 calls the present Parliament Buildings "shrines to our freedom," a phrase that may ring oddly in some Canadian ears. ${ }^{19}$ The question arises, however: how was the architecture interpreted in its own time? Even making allowance for historical bias, we can safely say that the project of building Parliament was indeed viewed as a national enterprise. ${ }^{20}$ Choosing Ottawa as a permanent capital, amid whatever controversy, and hastily beginning construction there, for practical and ceremonial purposes, of public offices of unprecedented size and magnificence were viewed as indispensable symbolic tasks. But symbolic of what, exactly? Earlier we read John Bland's state- ment, "At the time of their construction, the Parliament Buildings in Ottawa were intended to be symbols of the immense achievement of political union." But that is a prime example of mid-twentieth-century myth-making with little historical basis. In fact, when work began in 1859 on the building of Parliament in Ottawa, the Union government had reached a state of procedural paralysis and of debt so deep - accumulated in overbuilding canals and railways at public expense - that Canada's continuation in its existing form was widely doubted. ${ }^{21}$ So, triumphalist interpretations will not do; it is probably more responsible, instead, to understand the project to build lavish new Parliament houses in a dubious location as compensation for widespread discouragement and disillusionment at the country's future. Accordingly, problems arise when modern commentators, conflating today's nationalism with that of the nineteenth century and attributing to Canadians of the period a cast of mind foreign to them, read the bold High Victorian Gothic of the central Parliament house and its departmental flankers as archetypally Canadian. ${ }^{22}$ I repeat, the question is: how did contemporaries read the architecture of Parliament? Addressing that question - the subject of the rest of this article requires the reader to have in advance a capsule-history of the building project. ${ }^{23}$

After Queen Victoria designated Ottawa (the former Bytown) permanent capital of the United Province of Canada the joint entity comprising Québec and Ontario, then called Canada East and West, respectively - a design competition was announced in May 1859 for new parliamentary and departmental buildings, parliamentary library, and governor general's residence to be erected on Barrack (or Barracks) Hill, an eminence north of the town overlooking the Ottawa River and west of the deep cut through which the Rideau Canal drops (by locks) to the river. The choice of Ottawa, however plain its beginnings, can be attributed in large part to what Victorians recognized as a highly picturesque situation. Governor General Sir Edmund Head, who favoured Ottawa over larger, established towns, is believed to have used a sketch of Barrack Hill by Lady Head to help persuade the Queen, herself a watercolourist, of the beauty of the spot, where, one suspects, he already envisioned a complex of government buildings. ${ }^{24}$ This raises the provocative question of whether the Parliament Buildings are where they are because Ottawa was made capital, or the reverse. In any event, by August of that year sixteen designs for a parliament house - more than for any other unit of the complex - had been submitted by architects, based for the most part in Canada. (One might have expected more foreign entries in a competition for buildings expected to cost well over half a million dollars, then a gigantic sum.) Most schemes were informed by the classic, symmetrical neo-Palladian tradition that had been favoured in the colonial period, and few demonstrated 
Figure 2. Stent \& Laver, architects. Bird's-eye view, 1859, of proposed parliamentary and departmental buildings, Ottawa. Drawing in ink, wash, and graphite, heightened with white, on wove paper. National Gallery of Canada (transfer from the office of the Dominion Chief Architect, 1882).

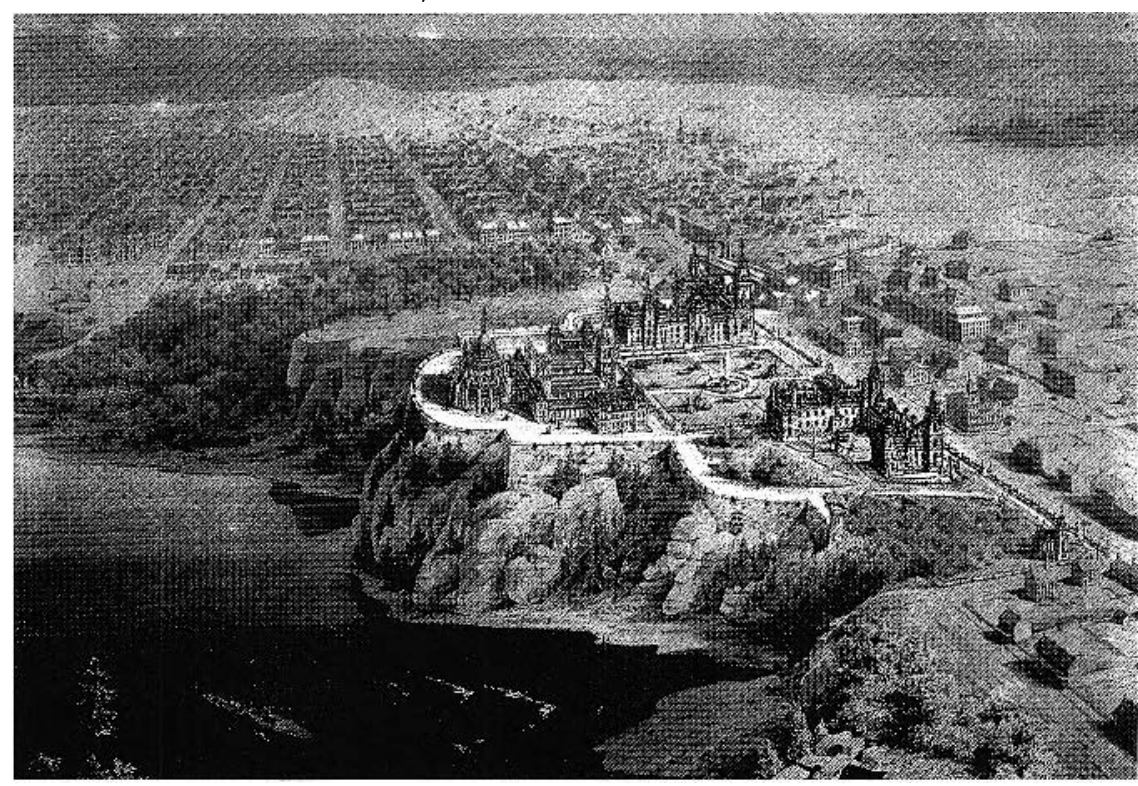

awareness of the recent revolution in eclectic High Victorian design that had galvanized the British architectural profession and public in the 1850 s. $^{25}$ Surprisingly perhaps, in a decision that moved Ottawa briefly to the forefront of international developments, precisely the most radical projects were chosen. ${ }^{26}$ A "modern" or "Ruskinian" Gothic design by the recently-arrived English architect Thomas Fuller and his Canadian partner Chilion Jones (1835-1912) was awarded the premium for the parliament house and attached library (fig. 2), while similarly animated neo-Gothic designs, also by English architects, Thomas Stent and Augustus Laver, were chosen for the departmental buildings, to be erected to left and right. The three buildings would frame "Parliament Square" facing Wellington Street and the town (fig. 3).

Despite its rugged neo-Gothic vocabulary, the central parliament house retained neo-Palladian frontal symmetry, with a plan organized around matching legislative chambers for the provincial Assembly and Council - later the House of Commons and the Senate - which were placed to either side of a striking central tower and a "public hall" for ceremonial, especially vice-regal, arrivals (fig. 4). Though familiar enough today, the plan developed by Fuller - probably the effective designer was something of an innovation in its time. A precedent for its symmetrical arrangement can be identified in the sequence of chamber-corridor-lobby-corridor-chamber of the Houses of Parliament at Westminster as newly rebuilt (1836-1860);27 but the most likely source for the plan's strict bilateralism and the emphatic outward expression of that was the symmetrical, bicameral American legislature type. If that seems a bold suggestion, consider the probabilities. For a small (probably two-man) architectural office to meet the tight deadline imposed by a short competition to design a relatively novel building necessitated turning to a suitable precedent. The American capitol type, geographically and culturally near at hand, was a self-conscious and already well-developed built expression of institutions of liberal self-rule. ${ }^{28}$ Though Fuller had not to our knowledge yet travelled in the United States, he would have had ready enough access to published views of the federal capitol, at least, which were widely circulated during T.U. Walter's additions to it in the $1850 \mathrm{~s}^{29}$ No British public-building type, even the town hall, of which many had recently been built, including one by Fuller himself, could match the American capitol for functional or symbolic suitability. ${ }^{30}$ Furthermore, the fifties were a decade of trade reciprocity and relative harmony between Canada and the United States, when "American" values of self-government and social egalitarianism rose sharply in Canada despite continuing intense immigration from the British Isles. ${ }^{31}$ At the time responsible government was being invented, it was at least clear that the Canadian elected and appointed chambers must be of equal size and dignity, a message the frontal symmetry of Fuller \& Jones's design sent effectively, if through a screen of anglophile, pointedly traditionalizing neo-Gothic detail. For these reasons, elsewhere I have called Fuller \& Jones's parliament house "an extraordinary fusion of types - a Victorian Gothic parliamentary capitol." 32

In every respect Fuller \& Jones's design for Parliament combined Anglo-American modernity with aggressive historicism. Offices, lounges, committee-rooms, and official apartments, marking a growth of both ceremonial and bureaucracy in the period, would occupy the perimeter and corner pavilions of the parliamentary building. Backing onto the bow-shaped cliff behind and attached to the main building by a corridor designed to assure quier and to reduce the risk of fire would be a striking polygonal library, the object of singularly careful planning and, when at length completed in 1876, particular praise. A residential government house was to have been notched into the ell between the library and Senate wing but was almost immediately dropped from the programme to save money.

Despite a prototypical Victorian building-history of unfathomable cost overruns, an enquiry into charges of waste and graft, and maddening delays in construction, the buildings in Ottawa were in shape to be occupied by the Union government when it moved from Québec City in the fall of $1865 .{ }^{33}$ In the 


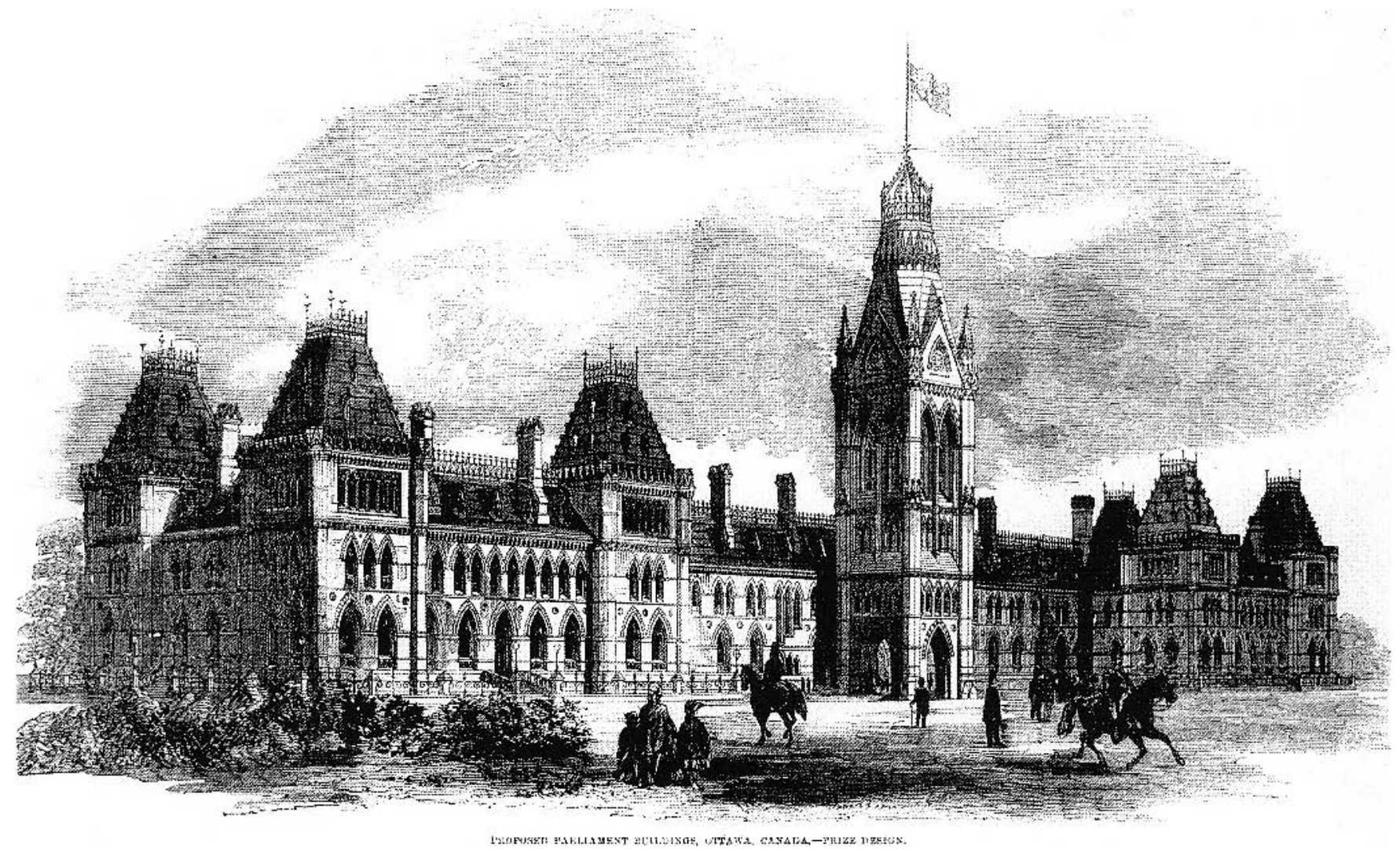

meantime, agreement had been reached between the two Canadas, Nova Scotia, and New Brunswick to form a larger federation, to be called the Dominion of Canada, with the aim of relieving the chronic stresses in the Union government stemming from differences in language, culture, and religion. Effective 1 July 1867, the Dominion legislature and administration, which essentially continued the corresponding bodies of the Union, took custody of the buildings on "Parliament Hill." 34

The complex was the pride of Confederation, lauded by visitors and critics. As that confederation expanded in the early seventies, however, the Parliament - like the Congressional chambers in Washington two decades before - soon became too small for its purpose and was disparaged as an ill-lit, stuffy, and overcrowded firetrap. ${ }^{35}$ Always aesthetically admired but never a true practical success, the building was enlarged once and continually altered. As Chief Architect in the Department of Public Works in the 1880s and 1890s, Fuller tinkered with his own building almost uninterruptedly. ${ }^{36}$ It may safely be said that the House of Commons building, as some called it, was not universally mourned when fire reduced it to rubble in February 1916. Fortunately, the blaze was confined to the central building; the library was saved by the fireproof iron doors in the linking corridor, and the East and West Blocks were untouched. These - also enlarged and repeatedly altered - continue to serve the needs of Parliament. ${ }^{37}$ Fuller \& Jones's parliamentary block was replaced by the present one, now known as the Centre Block, which was occupied in 1920 and is a much enlarged, steel-framed, streamlined, modernized Gothic version of its knobbly Victorian predecessor (fig. 5). The bold choice of High Victorian Gothic in 1859, then, effectively determined the architectural character of the whole precinct - arguably, the entire federal centre - until the present. ${ }^{38}$

With this factual skeleton in place, we may return to the question of how Parliament is and was represented in word and image. Representing Parliament began as soon as - indeed before - construction did: Canadians were proud of the government complex rising in the new capital. But what model of their country did they presuppose? Did they imagine Canada as a country? Or was it an imperial province, or still a colony? Terminology and constitutional theory and practice were mutating rapidly; mental constructs were fuzzy. Canadian selfidentity and patriotism in the Union period are too large a topic to address in detail here, but two points can reasonably be made. The first is that, though the Canada for which the 

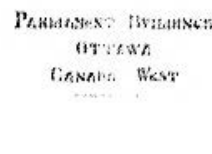

Figure 5. John A. Pearson and J. Omer Marchand, architects. Centre Block of Parliament as rebuilt 1916-27. (Photo: slide collection, Department of History in Art, University of Victoria).

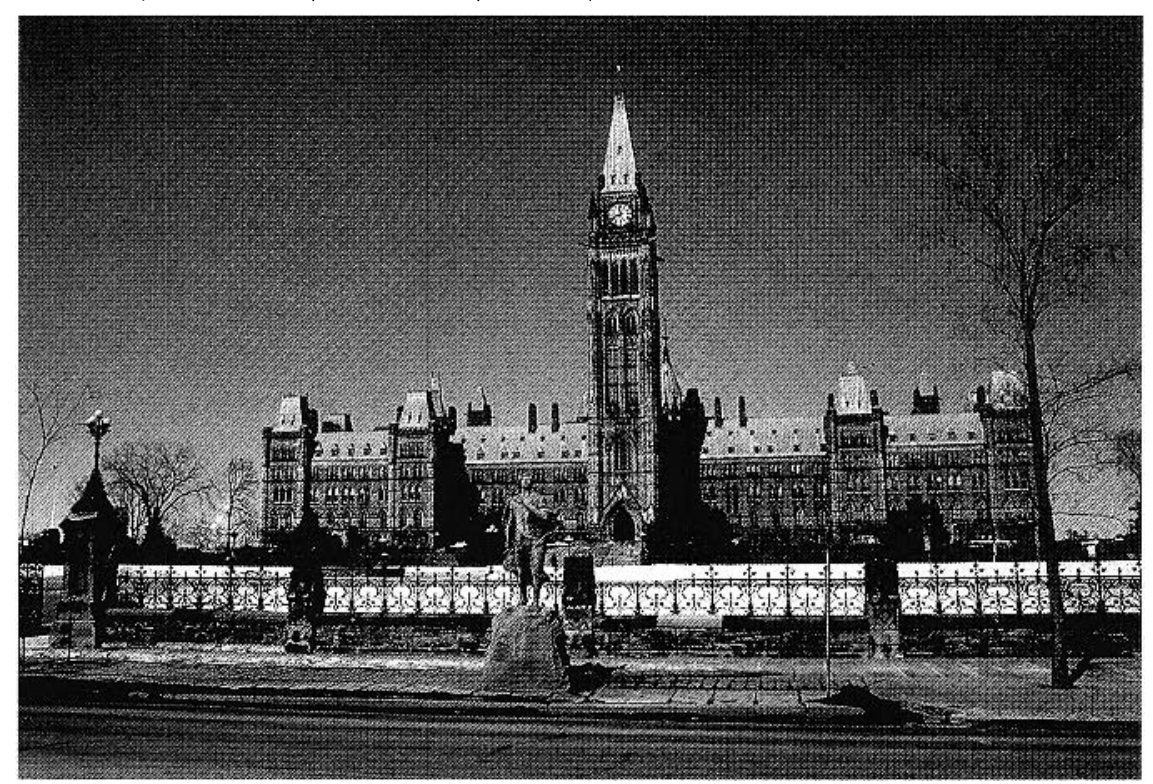

complex in Ottawa was built was, formally, the United Province organized in 1841, by the late 1850 s a far larger, even transcontinental Canada was heaving into view - a dream or imaginary that justified the building of a Parliament of some size, splendour, and ambition. ${ }^{39}$ Canada in its Union period nourished a number of progressive discourses, including those of responsible government, Reform politics, a liberal press and economy, and Victorian inventory science; collectively, these represent the cusp of processes of modernization in Canada. To them, the dream of a confederated, moderately self-governing, sub-imperial Canada an empire within the Empire - stretching from the Atlantic to the Rockies, incorporating if possible Vancouver Island and main- 
land British Columbia (so named and constituted in 1858), became the constitutional corollary and analogue. ${ }^{40}$ Reform interests in Ontario, especially Toronto, preached Confederation as a goal, and one could argue that, as modern Toronto is a product of the confederated Canada, so Canada is a product of Toronto! Legal niceties aside, it was the modern, transcontinental nation "Canada," implicitly, for which the parliamentaryadministrative complex in Ottawa was erected, although the complex proved too cramped for the purpose. That argument may seem to contradict the one I have been at pains to make about the danger of attributing current ideas of independent nationhood to Canadians of the mid-nineteenth century, but it can be defended on the basis of period ideas of Canada, ideas I will nuance and refine. That is the first point to be made about Union-era nationalism.

The second may seem both obvious and, again, contradictory, but that is the sort of idea most easily missed. Few English Canadians of the late 1850s imagined a collective future for themselves outside the British Empire for, however weak and fractured the Empire was just then, it was the indisputable frame within which Canada's imagined future hung. ${ }^{41}$ Governor General Head, who supported plans to confederate the British North American provinces, described these provinces as "a free people bound [to Britain] by the ties of affection and gratitude." 42 Most influential English Canadians would have agreed with him, some rabidly. Alexander Morris, considered a "boomer" of plans to federate a greater Canada and annex to it the Hudson's Bay Company lands in the Northwest, called Canada this "fertile British Province," Nova Britannia. ${ }^{43}$ To most Canadians today, for whom (virtual) constitutional independence is a sine qua non of nationhood, to conjoin Canadian nationalism to British imperialism seems paradoxical and contradictory; yet for nineteenth-century English Canadians and significant numbers of French it was nothing of the kind, argues Carl Berger. ${ }^{44}$ They saw Britain's support as not just desirable but essential to Canada's survival as a free nation, an idea that did not change until well into the twentieth century. Fascinatingly, recent historiography suggests that, natural though colonyto-nation models of Canadian history have come to seem since the 1920s, Canada berween the Napoleonic and First World Wars, besides remaining ethnically British to a high degree, may actually have "progressed" to more, not less, dependence on Britain! 45

The fact that mid-nineteenth-century English Canadians should more properly be called "Canadian British" - to quote Mary Vipond ${ }^{46}$ - seriously changes the way Parliament and its architecture are understood. Even subtle efforts to downplay the Britishness of Canada in the 1850s serve mainly to strengthen the mid-twentieth-century reflex to read this architecture as archetypally "Canadian." By contrast, I would argue, the build- ings in Ottawa, far from being less British in character than previous administrative architecture in "British North America," partook just as vigorously and expressly of it, if no longer through neo-Palladianism. The designs remained culturally, if no longer so politically, colonial, and even the latter is open to debate. Designed by two teams of newly-arrived English architects belonging to a wave of modern professionals who had immigrated to the province in the 1840 s and 1850 s, the Ottawa complex should be seen not, as it would later be, as an emblem of Canada's dual English-French personality, nor - slightly less anachronistically - of a fused, muscular Northern nationality; but as British buildings overseas, thoroughly imbricated in the English High Victorian revolution in public-building design. This point, though not exactly novel, has certainly not received the emphasis it deserves; and, when it has, everything looks different.

To take a specific and relevant example: scholars have long recognized that the design competition conducted in Canada in mid-1859 was overshadowed by the celebrated "Battle of Styles" that continued to drag on in London over the design of new Public Offices in Whitehall, an episode that pushed to the foreground the question of Gothic as a partisan political language. ${ }^{47}$ Thomas Fuller, the principal (if not sole) designing partner of Fuller $\&$ Jones, was certainly aware of that muchpublicized affair and had in fact been in a position, before leaving for Canada in mid-1857, to see the exhibition in Westminster Hall of rival designs for the Public Offices. ${ }^{48}$ Even once in Canada, he could keep abreast of developments in London by reading the mainstream and architectural press, which reached Canada readily. The coincidence of the two architectural dramas (or melodramas), at the imperial hub and in Britain's leading overseas white-settler province, has long been recognized, but the choice of a contemporary variant of neo-Gothic for Ottawa has been read as a matter of aesthetics and fashion, not in political terms. Although I too fail to reach a dramatic conclusion, I think it will be seen that the attempt to perform a political reading is worthwhile.

The narrative of events that began with - indeed before an international design competition held in London in 1856 for new Public Offices is highly confusing, but the essentials are as follows. The competition was apparently resolved in early 1858 by a Tory-dominated commission of enquiry in favour of designs by George Gilbert Scott for a suite of buildings (whose exact purposes need not concern us) in the revolutionary and eclectic neo-medieval design language that Ruskin promoted, known today as "High Victorian Gothic" (fig. 6). Scott's style was an adventurous and elaborate version of what Fuller \& Jones and Stent \& Laver would propose the next year for Ottawa, where cost, climate, and a frontier location favoured relative austerity. Reversing the selection of classical-Italianate 
Figure 6. George Gilbert Scott, architect. Design for Foreign Office, London, published in Illustrated London News, 12 June 1857.

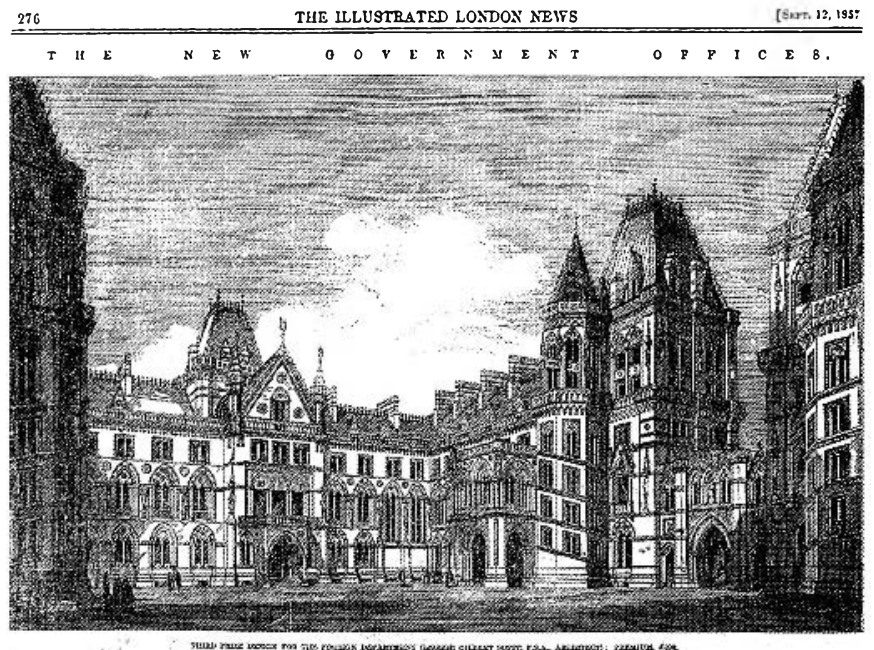

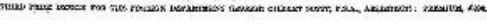

designs by lesser architects, made previously under the Whigs, the choice of Scott's neo-Gothic for Whitehall owed primarily to a stand taken by three highly-placed Tory politicians who, in public and private life, had long been partisans of advanced currents in the Gothic Revival: MP Alexander J. BeresfordHope, chairman of the Ecclesiological Society; Benjamin Disraeli, powerful Chancellor of the Exchequer and party leader in the Commons; and Lord John Manners, First Commissioner of Works. ${ }^{49}$ Fifteen years before, Disraeli and Manners had been leaders of "Young England," a movement to renew the Conservative Party by asserting the aristocracy's "natural" right to rule in urban, industrialized Britain, which had appropriated the growing neo-medievalism in all the arts, especially architecture, as an emblem of its political mission. ${ }^{50}$ Associations of the stylistic revival to Britishness, up to then hazy, had recently been refreshed and specified by the rebuilding of the burnt-out Houses of Parliament at Westminster in a version of late Gothic confected by Pugin: in Victorian Britain the architectural was political. By the 1860s, however, Brownlee concludes, to equate the Classic with Liberalism and the Gothic with Toryism in a simple oneto-one way, as one could have a little earlier, ${ }^{51}$ was out of date, for, as the debate on the design of the Public Offices wound on, Gothic's parrisan symbolism was muddied by some Liberals' (notably Gladstone's) embrace of the style, and by Scott's reluctant agreement - forced on him by the return to office of the Liberal Lord Palmerston, who detested neo-Gothic - to build in the classicizing Italianate or "Palladian" style. Nevertheless, the affair itself argues that those equations still enjoyed some limited currency; and, pace David Brownlee, I conclude that, by tradition if no longer general practice, neo-Gothic did to a degree remain Tory symbolic ground.

A Canadian wonders, then, whether the partisan politics of style in London carried across the ocean to colour develop- ments in Ottawa. The unsatisfying answer, I think, is yes and no, because here stylistic politics were even more blurred than in the metropolis. The blurring is largely explained by the fuzziness of party lines in the United Province, as even the name of the alliance that governed (or tried to) during most of the construction period in Ottawa, "Liberal-Conservative," suggests. 52 That makes it hard to read partisan significance into the choice of style for the buildings intended to accommodate the government. Furthermore, most of those involved in judging the competition-entries were civil servants who downplayed personal political affiliations in order to base their claims to authority on technical expertise. The major exception was Governor General Head, who to some degree held a political appointment and demonstrably took a hand in selecting the winning designs. ${ }^{53}$ Might his partisan sympathies have played a role in the choice of Gothic for the buildings on Barrack Hill, as one tradition long held that to be the case? Early-twentiethcentury writer W.A. Langton, citing as his source C.P. Meredith, believed the choice of Gothic to have been "decreed"; 54 and, even recently, architectural historian Harold Kalman described Head as a "known connoisseur of Gothic architecture." 55 Attributing the choice of Gothic to him makes sense, given the impression he leaves of a sort of pre-Confederation Lord Dufferin - a skilled, activist executive who knew the value of culture to statecraft in a system that no longer allowed the Crown much direct authority. The problem with the theory is that it cannot be correct. True, Head respected the symbolic power of architecture, as his active role in developing the design of University College, Toronto, widely considered a formal precursor to Ottawa's Parliament Buildings, suggests. ${ }^{56}$ There he had rejected the use of Gothic out of hand - not what one would expect of a dedicated Gothic revivalist; perhaps Head's tastes were more complex. I would argue that the stylistic position he took in Toronto by insisting, first, on the use for the college building of the "Italian" - Italian Romanesque, to us - and, later, the "Byzantine" was precisely in character for one who was by training and disposition a Classicist. "[O]ne of the most accomplished linguists and philologists of his generation," 57 an art historian whose knowledge commanded respect in the clubs and salons of London, Head before entering the colonial service had studied Classics, lectured at Oxford, travelled, and edited and translated a handbook of the history of painting. He no doubt knew his architecture: to that degree, Kalman is right. But to imagine Head as a partisan of the Gothic Revival is surely wrong. His consistent distaste for "exclusiveness or the tendency to depreciate that which does not at once conform to our own tastes and feelings" would have made him uncomfortable with the relatively doctrinaire tenor of the Gothic Revival before 1860, even had he been a Tory; 58 but a Tory he was not. Though diplomatic enough to keep his party loyalties to him- 
self while in British North America, at home in England Head, like Lord Durham, whose system of responsible government he largely implemented, was a Whig, as Liberals were called until the mid-fifties. ${ }^{59}$ A reformer, moderate, and thorough modernist (though given, Canadians thought, to off-putting arrogance in personal dealings), Head had views that suited an emerging nation-state that valued above all commerce, liberal politics, and "internal improvements"- chiefly canals and railways. If anything, the aesthetic taste he demonstrated in Toronto reinforces the traditional association of classical styles with Whiggery; certainly it fails to explain why High Victorian Gothic was adopted in Ottawa. That fact tends, rather, to support the claim that the premiated designs won because they were expected best to meet utilitarian demands while creating overall visual harmony and a striking appearance and silhouette on a spectacular site.

Does this laborious and undramatic discussion of partisan politics and architectural style in pre-Confederation Canada, then, lead only to a dead end? It certainly seems that equations of parties to architectural styles at the imperial centre in London, even in the softened state these had reached by the late fifties, obtained in only the loosest fashion in Canada. Can no more be said? However apparently obvious, another point can be made - and should be, if Parliament's architecture is to be situated in the taste of its times. In the context of AngloCanadian culture of 1860 , to build in neo-Gothic on Barrack Hill in Ottawa, though it did not specifically connote Toryism, was ringingly to endorse ties to the Mother Country at a moment when Canada's political future was mooted. To quote Chris Brooks - of all historians of the Gothic Revival, perhaps, the one most given to reading it in political terms: "In a colonial set-up ... Gothic affirmed identity and togetherness of settler societies, even if it erased indigenous memories and had nothing to do with actual history." ${ }^{60}$ In short, to design in the revived Gothic in Canada in the late 1850s connoted Britishness in general; and few were more aware than Thomas Fuller of Gothic's ability to signal relations of class, ethnicity, and nationality and to exploit that ability at a historical moment charged with tension for Canada's future. Newly arrived from Bath and London, he lived and operated in a veritable Nova Britannia. His partner, civil engineer Chilion Jones, was the scion of a Family Compact clan from Brockville, on the heavily Loyalist $\mathrm{St}$ Lawrence River front. ${ }^{61}$ The staple of their Toronto-based practice (which in its first year had included a third partner named Robert C. Messer) before they won the competition in Ottawa, had been building churches, mainly Anglican, in southern and eastern Ontario and western Québec - vigorous and ecclesiologically accurate stone or brick buildings, detailed in the willfully crude High Victorian way. ${ }^{62}$ Highly responsive to considerations of class and ethnicity, these commissions formed profitable connections for Fuller in Anglo-Canadian, especially
Ontario Tory, circles, to which Jones may have introduced him. The major example, St Stephen-in-the-Field, built in 1858 on the growing northwestern edge of Toronto, was a "free" church built at the expense of a leading Tory Family Compact member, Robert Brittain Denison (fig. 7). ${ }^{63}$ Many architectural details later employed in the Parliament Buildings had been developed in simpler form for it and churches like it, however unlike Parliament the churches were in scale, plan, and ambition. In both his Canadian churches and his Parliament, each embodying its own political and cultural imaginary of Canada, Fuller was instrumental in building a white-settler Britain overseas. How different that version of Fuller is from the one I - an Ottawa-born, Toronto-trained Canadian nationalist of Trudeau's era - constructed in my thesis of 1978 is readily apparent.

Are we now forced to the opposite conclusion, then, that the neo-Gothic parliament house on the bluff in Ottawa had nothing "Canadian" about it? Yes, if Canadianness is understood to be an organic, autochthonous essence and not the complex cultural construct scholars today consider nationalism to be. ${ }^{64}$ Yet it is in the nature of potent cultural constructs to seem selfevidently natural; $; 5$ and, as I argued in the opening pages of this article, through most of the twentieth century the archetypal Canadianism of the Ottawa Parliament has been beyond question. Must that notion be discarded? Only if a literal understanding of what "Canadian" signifies is intended. But it never was: I contend that the label was simply adopted and circulated without being rigorously critiqued.

A better place to begin answering these questions is to inquire into what mid-nineteenth-century Canadians themselves, for whom the government complex in Ottawa was designed, understood by "Canadian." Here, the degree to which English Canadians, Ontarians in particular, assumed their collective character precisely to be Britons overseas must not be underestimated. Given that assumption, for contemporaries to associate modern Gothic architecture with Canada's character was both reasonable and evocative. Twice I have quoted the title - Nova Britannia - of a lecture given by Alexander Morris in 1858 , the great popularity of which suggests that it captured what his English-Canadian audience believed, or wished to believe, about themselves. ${ }^{66}$ Like most Canadian nationalist writing of the period, it echoed with optimism that Canada in whatever form - imperial province or federated nation - would gradually grow in self-respect, independence, and international stature without, as the founders of the United States had, severing ties of political and cultural loyalty to Home. Indeed, through most of the nineteenth century the capacity to harmonize novelty with tradition was considered Canada's chief virtue. In an address of 1857, Chief Justice William Henry Draper praised Canadians for their "body of law devised by the wisdom of past ages, and improved by the experience of successive generations; 
Figure 7. Thomas Fuller, architect. Perspective drawing for Anglican church of St Stephen-inthe-Fields, College Street \& Bellevue Avenue, Toronto, 1858. Toronto Public Library (TRL): $972 \cdot 1 \cdot 1$.

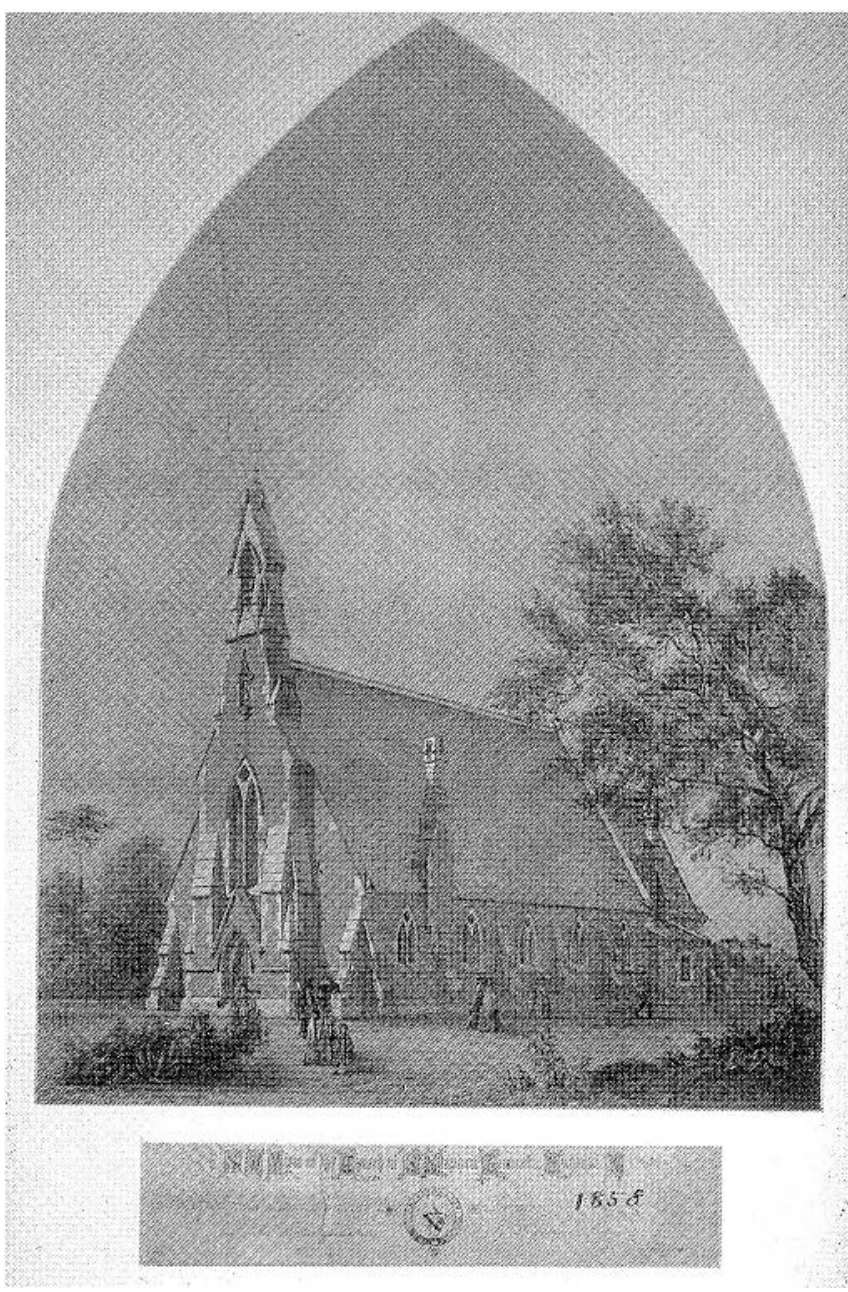

a constitution, which confers the privilege and imposes the obligation of working out the problem of self-government under the guardianship of the Mighty Empire of which we form part; and above all these: for their guiding star, Christianity." 67 Parliament, the emergent nation's supreme lawmaking institution, was designed in just this attitude of cultural and political incrementalism, which corresponded aptly to the notion of "development" from antiquarian copyism to rational modernity that underpinned High Victorian aesthetic theory, with its ideal of "Modern Gothic." In this respect one is inclincd to agree with Fuller \& Jones's argument that for the site and purpose "Gothic is not only the best, but the only rational architecture." ${ }^{8}$ Neither contemporary architectural theory nor English Canada's collective self-image required one to choose between tradition and reform, for building, like the society it served, was irreversibly set, according to the Victorian credo of progress, on a path toward a new and higher order governed by God. ${ }^{69}$ And nowhere, perhaps, was harmonious, frictionless Progress so free to stage itself as in Canada, the "empty" North Atlantic settler colony fast being cultivated and "civilized" by stout-hearted British yeomanry and bourgeoisie, which, eschewing "Americans"" despised pattern of revolution and extremism, fused loyalty to the Old with vigorous, hopeful pursuit of the New. For such a people, contemporary Gothic was a modernizing mode that could bridge the anxiety-provoking canyon yawning between the Middle Ages and Victoria's reign, between Home and Canada.

Viewed in light of contemporary English-Canadian thought and architectural theory, then, the Victorian Gothic chosen for the new buildings at Ottawa was emblematically Canadian, and to that degree the festive historiography of the Centennial period was justified in what might be called retrojecting into the nineteenth century a nationalist cultural project expressed in, or mediated by, the form of a "Canadian Gothic." That move put historians into a dilemma, however - one they ought perhaps to have acknowledged - that by the 1950s "Canadian" arguably signified the direct opposite of what it had a century before: an independent, autochthonous collective identity, as opposed to one continuing historically from, and relying upon, those of Britain, Europe, and the U.S.A. Hence, Centennial-era claims exude a whiff of bad faith and intellectual sleight-of-hand when scrutinized in retrospect.

One is left to ponder how the wound that opened between the two halves of Morris's phrase Nova Britannia - "new" and "Britain" - can be sutured, a question that has preoccupied writers on Canadian culture since at least the Act of Union. Nineteenth-century English Canadians felt compelled by imperatives of Nationalism and Progress to forge an authentic or organic culture distinct from Britain's yet had only the pieces of the Anglo-Amcrican culture(s) to which they had access to accomplish that with. Culture-formation in Canada entailed agonizing inconsistencies and acts of rhetorical repression and condensation, tensions that manifest themselves in the verbal and visual discourse that clustered around Parliament's architecture in the late nineteenth century. ${ }^{70}$ How the complex in Ottawa was re-constructed in rhetoric and visual culture after its opening must be considered elsewhere, though: here I can only juxtapose the discourse about Parliament at two critical moments, Confederation and its centennial.

Working as we still do in the shadow of the substantial volume of writing on Canadian culture undertaken in the $1960 \mathrm{~s}$ and 1970s, cultural historians and critics today have the major task of revisiting and problematizing that writing. Symbolic readings offered then of the Parliamentary neo-Gothic as embodying a putative unitary Canadian spirit, when put under the microscope, turn out not so much to be wrong - indeed, they have proven extremely durable, rich, and provocative for readers in a country obscssed with its own place and identity - as to be partial, unstable, and time-conditioned. Those formulations 
concealed a shifting world of other meanings of Canada, federalism, government institutions, architectural styles, and Canadian peoples; and reexamining them invites fresh particularity and fine grain in scholarship, along with the marshalling of evidence and arguments from disciplines outside the history of art and architecture. What will emerge from studies like this, I think, is a more complex and cosmopolitan portrait of midVictorian Canada than that of the classic Canadian architectural history, a portrait in which nineteenth-century official Canada is shown suspended in a cat's-cradle of meanings conventionalized within the Anglo-American cultural matrix of which Canada was part. One verity about Parliament's architecture seems to be that it was a product of British theory and practice slipped over a plan developed for a public institution in the United States. Beyond that, all is, and always was, reading.

\section{Notes}

1 Alan Gowans, "The Canadian National Style," in W.L. Morton, ed., The Shield of Achilles: Aspects of Canada in the Victorian Age (Toronto, 1968), 209. He had made substantially the same claim in his Looking at Architecture in Canada (Toronto, 1958), 145, and its newer, grander edition, Building Canada: An Architectural History of Canadian Life (Toronto, 1966), 118. Gowans's argument was based, in turn, on Carroll L.V. Meeks's identification of "picturesque eclecticism" as the unifying visual principle underlying High Victorian aesthetics: "Picturesque Eclecticism," Art Bulletin, XXXII (Sept. 1950), 226-35. For a more detailed discussion of these sources and, generally, of postwar critical attitudes to High Victorian architecture, see my article "'Canadian Castles?': The Question of National Styles in Architecture Revisited," Journal of Canadian Studies, XXXII (Spring 1997), 5-27, esp. nn. 5-7.

2 R.H. Hubbard, "Canadian Gothic," Architectural Review, CXVI (August 1954), 103. He had first advanced this argument in a conference paper given in January 1948, titled "Victorian Gothic in Canada": see Journal of the Society of Architectural Historians, VI (July-Dec. 1947), 6, 34. For other versions, see also Hubbard, "Architecture in Ottawa: A Personal View," Journal of the Royal Architectural Institute of Canada, XXXII (Nov. 1955), 410-13; and, much later, idem, "Modern Gothic in Canada," Bulletin of the National Gallery of Canada, XXV (1975), 3-18.

3 For a popular treatment of the Centennial and its mood, see Pierre Berton, 1967, the Last Good Year (Toronto, 1997). See also Thomas, "Canadian Castles?," 8 and n. 13.

4 For a use of "first" in this sense - strictly speaking incorrect, since a series of buildings in several towns (the capitals of various colonies and provinces of two empires) had been custom-built or, more often, appropriated for governing purposes since the seventeenth century - see the title of Carolyn A. Young's book The Glory of Ottawa: Canada's First Parliament Buildings (Montreal, 1995). It is an understandable slip of the tongue, however, since almost all literature on Canadian federal architecture originates in Ontario or
Québec, where it is widely supposed that, because the "real" Canada sprang into existence in 1867 or perhaps at the Union of those two provinces in 1841, the buildings that first housed its legislature must be Canada's first parliament - a great oversimplification. To date, the most complete sources on the earlier administrative buildings are two studies in the Library of Parliament: J.D. Livermore, "A History of Parliamentary Accommodation in Canada, 1841-1974," Report of the Advisory Committee on Parliamentary Accommodation ([Ottawa], 1976), app. III; and Audrey Dubé, "Historical Chronology of the Parliament Buildings," report for the Library of Parliament, Information and Reference Section, $1985,1-6$.

5 An influential example is Harold Kalman's discussion of the building of Parliament in A History of Canadian Architecture, 2 vols (Toronto, 1994), II, 534-41, esp. 541.

6 John Bland, "The Development of Canadian Architecture," Habitat, II (Jan.-Feb. 1959), 4-5. Significantly, Bland's later survey, published after Québec's Quiet Revolution in collaboration with Pierre Mayrand, called Trois siècles d'architecture au Canadal Three Centuries of Canadian Architecture (Montreal, 1971), contains no such quotable, "purple" prose about Parliament and sketches a binuclear model of Canadian architecture embodying dual "Canadas," English and French, with Canada west of Ontario figuring barely at all.

7 See Kelly Crossman, Architecture in Transition: From Art to Practice, 1885-1906 (Kingston, 1987), ch. 7, "The National Idea." Even Crossman's attention to the theme may itself be seen as a late manifestation of the patriotic obsession in what I call, elsewhere in this article, the classic historiography of Canadian architecture.

8 Annmarie Adams stresses the art-historical character of much writing about Canadian architecture; sce "The Monumental and the Mundane: Architectural History in Canada," Acadiensis, XXX (Spring 2001), 149-59. Art history as a systematic discipline began to appear in Canadian university curricula in the 1930s and more often after World War II, usually within fine art programmes that included (and tended to emphasize) studio practice. This was the story at the University of Toronto, where Peter Bricger brought art history to the curriculum in 1936, about the same time as studio art was first taught: Department of Fine Art/University of Toronto Newsletter, no. 1 (Fall 1987). I am grateful to Peggy Haist and Erin Campbell for this reference. At Queen's University, art history was taught by André Bieler at the Agnes Etherington Art Centre in the 1950s, a separate art history department being formed by Gerald Finley only about 1963. Thanks are due Bruce Laughton and John Osborne for this information. At UBC, Jill Wade informs me, Bert Binning probably offered art history courscs as early as the 1940s, well before the Board of Governors would authorize studio teaching. At the newer University of Victoria, created in 1963 (from existing Victoria College), Alan Gowans on arriving in 1966 insisted on separate art history and studio departments, giving the former the novel name "History in Art" to stress the documentary and evidentiary character of the arts in material culture. He was given memorably and amusingly to attacking the formalism and elitism he saw as endemic to art history. 
9 Here I have in mind especially the work of Vancouver architects Erickson \& Massey, in particular Simon Fraser University (196365), and the planning, design, and infrastructure of Expo 67. "Usable past" is a phrase introduced in the early twentieth century by American cultural critic Van Wyck Brooks: see "On Creating a Usable Past," in Van Wyck Brooks, the Early Years: A Selection from His Works, ed. Claire Sprague (Boston, 1993), 219-26.

10 On the cultural climate in Canada between the world wars, see Mary Vipond, "National Consciousness in English-Speaking Canada in the 1920s: Seven Studies," Ph.D. diss., University of Toronto, 1974.

11 "Canada and Its Poetry" (1943), in Northrop Frye, The Bush Garden: Essays on the Canadian Imagination (Toronto, 1971), 131.

12 On governmental support of arts and letters, see Karen A. Finlay, The Force of Culture: Vincent Massey and Canadian Sovereignty (Toronto, 2003), ch. 6. Toward 1970, the federal government itself became an agent of architectural history when it established the Canadian Inventory of Historic Buildings (CIHB) within the national parks service. The small bureaucracy researched and prepared briefing-papers on historic sites and buildings and sponsored the publication of a series of Canadian architectural style-studies. See Thomas, "Canadian Castles?," 10 and nn. 21-22; and Adams, "The Monumental and the Mundane," 151, 158. I am grateful to Leslie Maitland of Parks Canada for advice in preparing this note.

13 See Adams, "The Monumental and the Mundane."

14 James Viloria, "The Politics of the 'We' in the Construction of Collective Identities in Histories of Architecture in Canada," Journal of the Society for the Study of Architecture in Canada, XXIV, 4 (1999), 10-17.

15 From 1863 to 1875 , with a number of associates that included Augustus Laver (one of the partners in building the east and west departmental blocks in Ottawa), Fuller worked on the huge project of building a new state capitol in Albany, N.Y., and was associated, from 1871, with Laver in building a new city hall and law courts in San Francisco. On Fuller's life, see my biography of him in Dictionary of Canadian Biography [DCB], XII, 343-46.

16 Alan Armstrong, "Profile of Parliament Hill," Journal of the Royal Architectural Institute of Canada, XXXIV (Sept. 1957), 327.

17 See Lawrence J. Vale, Architecture, Power, and National Identity (New Haven, 1992). Seeking to rescue nationalism from its twentieth-century disrepute, Vale, on pp. 287-93, identifies the fcatures of a "good capitol," a composite which comes oddly to resemble the U.S. Capitol! Major commemorative monuments are also highly politicized, "impure" forms, as I observe in The Lincoln Memorial and American Life (Princeton, 2002), esp. xvii to xx.

18 Dell Upton, Architecture in the United States (Oxford, 1998), 75.

19 Mark Bourrie, Canada's Parliament Buildings (Toronto, 1996), 11.

20 So central was nationalism to the mid-Victorian era that historian E.J. Hobsbawm orients his international history The Age of Capital, 1848-1875 (New York, 1975) on "the principle of nationality."

21 On the period generally, see J.M.S. Careless, The Union of the Canadas: The Growth of Canadian Institutions, 1841-1857 (Toronto, 1967); and J.M. Bumsted, The Peoples of Canada: A Pre-
Confederation History (Toronto, 1992), ch. 10-12.

22 See also Thomas, "Canadian Castles?," esp. 6-10.

23 For a full account with ample bibliography, see Young, Glory of Ottawa; for an abbreviated version, Kalman, Architectural History of Canada, II, 534-41.

24 See D.G.G. Kerr, Sir Edmund Head, A Scholarly Governor (Toronto, 1954), 177.

25 On the transformation, see David Brownlee, "The First High Victorians: British Architectural Theory in the 1840s," Architectura, XV, 1 (1985), 33-46; and Chris Brooks, Gothic Revival (London, 1999), ch. 11.

26 How radical the group was can be gauged from the verdict of the respected architectural historian Henry-Russell Hitchcock, who called it "a major monumental group unrivalled for extent and complexity of organization in England": Architecture: Nineteenth and Twentieth Centuries (Harmondsworth, 1958).

27 At Westminster, a spine of ceremonial spaces occupies the core of the complex but is, in any case, not rigorous and is concealed on the south (river) side by office-wings and offset on the north by the projection of Westminster Hall, saved from the fire. See Chris Brooks's useful semantic reading of the plan in Gothic Revival, 209-14.

28 On American capitols, almost universally marked by neoclassical bilateral symmetry, see Henry-Russell Hitchcock and William Seale, Temples of Democracy: The State Capitols of the U.S.A. (New York, 1976), esp. ch. 3 and 4 (on approximate contemporaries of the Ottawa Parliament). On the federal Capitol, just then undergoing major expansion and reconfiguration, see Pamela Scott with the Library of Congress, Temple of Liberty: Building the Capitol for a New Nation (New York, 1995), esp. epilogue.

29 The U.S. Capitol was the subject of many published prints and photographs during the building-campaign of that decade; Baltimore printer Edward Sachse was particularly associated with the former. Examples of his prints of the Capitol appear in John W. Reps, Washington on View: The Nation's Capital Since 1790 (Chapel Hill, 1991), folio 40.

30 Until the passage of the Municipal Reform Act in 1835, the town hall was an almost unknown building-type in Britain. After it, a stream of building-designs, showing a good deal of confused uncertainty about the type, poured from architects' offices. See Colin Cunningham, Victorian and Edwardian Town Halls (London, 1981), esp. ch. 1. For Fuller's town hall at Bradford-on-Avon (1853), described as a "jolly Jacobethan pile," see 65, 262-63.

31 An introduction to Canadian-American relations in the period appears in Robin Winks, The Civil War Years: Canada and the United States, 4th ed. (Montreal, 1998).

32 In a review of Young, Glory of Ottawa, published in Journal of the Society of Architectural Historians, LVI (June 1997), 234. The argument in this paragraph in no way intends to refute the idea - first advanced by Douglas Richardson, I believe - that the symmetry, formal character, and mansarding of Fuller \& Jones's parliament house derived from familiarity with the design of wings newly added to the Louvre. Tracing architectural influences is rarely an "either-or" matter. On the contrary: Visconti and Lefuel's "new 
Louvre" was by all accounts the most influential public administrative building of the 1850s in Euro-America: see M.H. Port, Imperial London: Civil Government Building in London, 1850-1915 (New Haven, 1995), 14-15. I do contend, though, that each - the Louvre and the American capitol-type - not to mention other High Victorian public-building designs, unexecuted and executed (including University College, Toronto, and the new Oxford University Museum), which combined frontal symmetry with neomedieval detail, would have reinforced for Fuller the symmetry and classical formality of the other, increasing rather than decreasing, as I see it, the likelihood that the capitol-type was his most pertinent model.

33 On the move to Ottawa, see Sandra Gwyn, The Private Capital: Ambition and Love in the Age of Macdonald and Laurier (Toronto, 1984), esp. ch. 2 and 6. In fact, the Union parliament sat in session only once in the new building, in 1866 .

34 Construction, once re-commenced after the enquiry, was phased to spread costs, with the result that only much later were the Victoria Tower (1873) and Library of Parliament (1876) completed - the latter to a design altered to incorporate the first alliron roof structure in Canada. By then, the West Block was already being enlarged with new wings and its tall trademark tower, "Mackenzie's Cowbell."

35 In fact, the roof and ceiling of the House of Commons did catch fire in 1879: Dubé, "Historical Chronology," 12.

36 His additions and alterations are summarized in Dubé, "Historical Chronology," but fully documented in National Archives of Canada, RG 11 (Public Works), Chief Architect's correspondence.

37 At Confederation the government's entire headquarters staff of fifteen administrative departments was housed in the trio of buildings, and a small structure west of them, on Parliament Hill. Today the complex on the hill serves the needs of Parliament alone, inadequately at that. Major expansion and renovation of the "Parliamentary precinct" were undertaken in 2001, a campaign that will entail filling the light-courts of the East and West Blocks and shoehorning new buildings in at the edges of Parliament Hill: see "A Legacy for Future Generations: The Long Term Vision and Plan," linked on the Internet to www.parliamenthill.gc.ca/text/ visionandplan_e.html.

38 On Parliament's twentieth-century neo-medieval neighbours, see Thomas, "Canadian Castles?," 10-13 and nn. 23-25.

39 On nationhood as an artifact of the collective imagination, see Benedict Anderson, Imagined Communities: Reflections on the Origin and Spread of Nationalism, rev. and extended ed. (London, 1991).

40 See J.M.S. Careless, Brown of the Globe, 2 vols (Toronto, 196063), esp. I., 305-28, and II, ch. 4; and Suzanne Zeller, Inventing Canada: Early Victorian Science and the Idea of a Transcontinental Nation (Toronto, 1987); and idem, Land of Promise, Promised Land: The Culture of Victorian Science in Canada, Canadian Historical Association Historical Booklet \#56 (Ottawa, 1996).

41 See Carl Berger, Imperialism and Nationalism, 1884-1914: A Conflict in Canadian Thought (Toronto, 1969), which, however, focuses on a later period. Imperial ties, if not British ethnicity (which remained strong), were perhaps at their weakest in the $1840 \mathrm{~s}$ and 1850s, when Liberal free-traders in Britain eliminated mercantilist tariffs that protected markets for Canadian raw products, creating panic and hardship in Canada and spawning a short-lived movement for annexation to the United States, which failed but did lead to trade reciprocity for another decade.

42 Head, memo of 1850-51, quoted in James A. Gibson, "Sir Edmund Walker Head," DCB, IX, 382.

43 "Fertile": Alexander Morris, Canada and her resources, pamphlet, 1855. Nova Britannia, or, British North America, its extent and future is how he titled a lecture of 1858 , read widely in pamphletform. See $D C B, \mathrm{XI}, 614$.

44 See Berger, Imperialism and Nationalism.

45 Colony to Nation is the sub-title of A.R.M. Lower's influential history Canada, first published in 1939. For the current viewpoint noted here, see Ged Martin, "Canada from 1815," in Andrew Porter, ed., The Oxford History of the British Empire: The Nineteenth Century (Oxford, 1998-99), 522-45.

46 Vipond, "National Consciousness," 13, in reference to the English-Canadian intellectual élite of the 1920s.

47 See David B. Brownlee, "That 'regular mongrel affair': G.G. Scott's design for the government offices," Architectural History, XXVIII (1985), 159-97; Ian Toplis, The Foreign Office: An Architectural History (London, 1987); and Port, Imperial London, ch. 13 and passim.

48 On Fuller's life, see my biography of him in DCB, XII, 343-46. He first advertised his presence in Toronto in September 1857; the exhibition in I.ondon had opened on May 4: see Brownlee, "That 'regular mongrcl affair'," 164.

49 Brownlee, "That 'regular mongrel affair'," 166-68; and Port, Imperial London, app. 1 and 4.

50 Brownlee, "That 'regular mongrel affair'," 167. On Young England, sec Alice Chandler, $A$ Dream of Order: The Medieval Ideal in Nineteenth-Century English Literature (Lincoln, NB, 1970), ch. 5.

51 Whig affinity for Palladianism - more properly, neo-Palladianism - is considered to date from ca. 1715 and to be epitomized in Lord Burlington's choice of style for his Chiswick House, of ca. 1725: see John Summerson, Architecture in Britain 1530 to 1830, 7th (3rd integrated) ed. (Harmondsworth, 1983), ch. 20, esp. 319-21. It is harder, though, to document an early and strict equation of the Gorhic with Toryism, for the style (or family of styles), though revived in the eighteenth century, appears for some time to have had hazier sign-value embedded in culture, generally, rather than partisan politics, until the time of Pugin, the Ecclesiological Society, and Young England - approximately the late 1830s to 1850 by which time the currency of the equation cannot be disputed: see Brooks, Gothic Revival, passim.

52 Party politics of the later Union period are an almost hopeless tangle, suggesting the impasse into which the system of government had fallen by the late 1850s. "Liberal-Conservative" identifies the alliance between Tories of Canada West and French-Canadian Reformers, Liberals, or Rouges of Canada East that governed for most of the decade after 1854; after 1857, under joint ministries headed by John A. Macdonald and Georges Étienne Cartier. Even this is not so simple as it sounds, for the period 
1861-64, alone, saw two elections and at least four governments (and a brief period with no government at all!). The deadlock between the sections was broken in June 1864 by the formation of the so-called Great Coalition between George Brown's (Ontario) Reformers, Macdonald's Conservatives, and Cartier's Rouges for the purpose of negotiating a confederation with the Maritime provinces. For details, see Jay Myers, The Fitzhenry \& Whiteside Book of Canadian Facts and Dates (Markham, ON, 1986), 116-23.

53 Instead of passively accepting the recommendations of Public Works officials, Head, a "hands-on" executive, altered the point-system on which the entries had been judged, thereby influencing the outcome: Young, Glory of Ottawa, 67. On Head more generally, sce Kerr, Sir Edmund Head.

54 W.A. Langton, O.A.A., "Canada's National Buildings ... A Review of Their Construction, Arrangement, Relative Positions and Architectural Detail," Construction, II (Nov. 1908), 47.

55 Kalman, History of Canadian Architecture, II, 534.

56 Sec Douglas Richardson, A Not Unsightly Building: University College and Its History (Toronto, 1990), 52, 59, and passim. See also Geoffrey Simmins, Fred Cumberland: Building the Victorian Dream (Toronto, 1997), 106.

57 Gibson, in $D C B, \mathrm{IX}, 381$.

58 "Exclusiveness": Head, quoted in Kerr, Sir Edmund Head, 236.

59 Head's affiliation with the Whigs had delayed his appointment as a Poor Law commissioner, before he had entered the colonial service: see Kerr, 14, and Dictionary of National Biography, IX, 323-24.

60 Brooks, Gothic Revival, 288. To which I respond: Were historical memories of England cherished by emigrants to Canada less "actual" than those of countrymen who stayed home?

61 On Jones, see his wife's biography: S. Lynn Campbell and Susan L. Bennett, "Eliza Maria Harvey," DCB, XIII, 454-55.

62 On the churches, see Thomas, "Fuller," $D C B$, XII, 344; and idem, "Dominion Architecture," 54-59. In addition, Joan Rooney has recently come across village churches appearing, on stylistic grounds, to be Fuller's, in communities along the Ottawa River in Québec where, historically, English was spoken. I am grateful to her for making me aware of these.

63 On the church, see (besides sources cited in n. 62) Marion MacRae and Anthony Adamson, Hallowed Walls: Church Architecture in Upper Canada (Toronto, 1975), 159; and material newly compiled by Sandy Gillians in http://www.saintstephens.ca/history.htm (a site I thank Gillians for bringing to my attention). On the wider religious movements in which St Stephen's took part, see Chris
Brooks and Andrew Saint, eds, The Victorian Church: Architecture and Society (Manchester, 1995); and William Westfall, Two Worlds: The Protestant Culture of Nineteenth Century Ontario (Montreal, 1989), csp. ch. 5.

64 See n. 39, above.

65 An argument I make in the U.S. context in Lincoln Memorial and American Life, esp. xvii-xx.

66 See n. 43, above.

67 From the peroration of an address to the Canadian Institute, reproduced in Canadian Journal, March 1857, 93.

68 Statement accompanying the firm's design-entry in 1859, cited in Young, Glory of Ottawa, 29, though in context the claim was more general - to the ability of modern civil Gothic to "fit itself most easily to all services, vulgar or noble."

69 On Victorian culture in Anglo-Canada, see Carl Berger, Science, God, and Nature in Victorian Canada (Toronto, 1983); A.B. McKillop, A Disciplined Intelligence: Critical Inquiry and Canadian Thought in the Victorian Era (Montreal, 1979); Westfall, Two Worlds; and Michael Gauvreau, The Evangelical Century: College and Creed in English Canada from the Great Revival to the Great Depression (Montreal, 1991). See also Robin Gilmour, The Victorian Period: The Intellectual and Cultural Context of English Literature, 18301890 (London, 1993).

70 An instance is the cultural criticism of John George Bourinot, longtime clerk of the House of Commons and probably Canada's most sustained and serious, if unadventurous, critic in the late nineteenth century. Bourinot scrutinized Canadian culture for signs of both originality and adherence to traditional ideals. Both an Impcrial Federationist and an admirer of highbrow American culturc, he commented on Canadian architecture only to lament its servility to Europe's and to regret the lack of an H.H. Richardson or World's Columbian Exposition as models to elevate public taste. He referred to Parliament's architecture only to commend its faithfulness to medieval models. On Bourinor, see Berger, Sense of Power, 20 and passim; biography by Margaret A. Banks in $D C B$, XIII, 98-102; and Bourinot collection in the Thomas Fisher Rare Book Room, University of Toronto Library, which includes copies of his books The Intellectual Development of the Canadian People in Historical Review (Toronto, 1881); and Our Intellectual Strength and Weakness: A Short Historical and Critical Review of Literature, Art and Education in Canada, Royal Society of Canada Series (Montreal, 1893). See especially the latter, 57-58, 89-90 (n. 64a). 